\title{
Reproductive strategies in two closely related stony corals (Agaricia, Scleractinia)
}

\author{
Godfried W. N. M. Van Moorsel* \\ Caribbean Marine Biological Institute (Carmabi), P. O. Box 2090, Curaçao, Netherlands Antilles
}

\begin{abstract}
Samples of the scleractinian coral Agaricia agaricites (Linnaeus) were studied for time of planula release, planula production and related characteristics. The corals were collected over a 2 yr period on the fringing reef of Curaçao at depths from 5 to $30 \mathrm{~m}$. Two distinct reproductive pattems emerged. Based on these patterns and on consistent differences in skeletal morphology, such as size of calices and number of septa, the separation of the form A. agaricites humilis Verrill as a distinct species, A. humilis, from the other forms of $A$. agaricites is proposed. A. humilis planulated throughout the year. A. agaricites shed planulae in spring and summer, a period of increasing sea water temperatures. In $A$. humilis $78 \%$ of the colonies $(\mathrm{N}=133)$ released planulae within 1 wk after collection, compared with only $26 \%(\mathrm{~N}=91)$ in A. agaricites. Maximum diameter of the smallest planulating colonies of $A$. humilis was about 4 times less $(28 \mathrm{~mm})$ than in A. agaricites $(108 \mathrm{~mm})$. Planula production per unit living tissue area was 4 times larger $\left(0.86\right.$ planulae $\left.\mathrm{cm}^{-2} \mathrm{wk}^{-1}\right)$ in A. humilis than in $A$. agaricites $\left(0.23\right.$ planulae $\left.\mathrm{cm}^{-2} \mathrm{wk}^{-1}\right)$. However, planula volume was 5 times lower $\left(0.166 \mathrm{~mm}^{3}\right)$ than in $A$. agaricites $\left(0.860 \mathrm{~mm}^{3}\right)$. It appears that $A$. humilis employs an opportunistic reproductive strategy compared with $A$. agaricites. A. humilis is mainly confined to the shallow reef flat and drop off zone ( 5 to $12 \mathrm{~m}$ ) and colony diameters rarely exceed $100 \mathrm{~mm}$. A. agaricites reaches its greatest abundance on the deeper reef slope $(10$ to $30 \mathrm{~m})$, growing to a maximum size of $600 \mathrm{~mm}$. The differences in reproductive strategies can be explained in relation to the predictability of their habitats.
\end{abstract}

\section{INTRODUCTION}

Aspects of reproductive patterns and other life history traits of benthic marine invertebrates, such as larval development type (planktotrophic, lecithotrophic or direct) or developmental period and egg size, are often interrelated to elucidate general patterns (Steele, 1977; Perron, 1981; Todd and Doyle, 1981).

Large-scale external factors such as latitude can influence reproductive characteristics (e.g. Corey, 1981; Spight, 1981; for review see Giese and Pearse, 1974); the increase of egg size in polar regions is even known as Thorson's rule (Clarke, 1979). But reproductive patterns can also be affected at one geographical location by environmental parameters such as depth (Corey, 1981; Karlson, 1982), height in the intertidal

\footnotetext{
- Present address: Institute of Taxonomic Zoology, University of Amsterdam, P. O. Box 20125, 1000 HC Amsterdam, Netherlands
}

(Hines, 1979; Spight, 1979), degree of exposure (FallerFritsch, 1977) or food source (Switzer-Dunlap and Hadfield, 1979).

Coral reef systems are characterized by limited spatial and temporal variation in temperature, oxygen and salinity (Ott, 1975; Dana, 1976; Ohlhorst, 1980), but there are significant gradients in exposure to water movement, irradiance and disturbance (Roberts et al., 1977; Van den Hoek et al., 1978; Bak and Luckhurst, 1980). The possible response to such gradients in reproductive patterns of the dominant reef builders, the stony corals (Scleractinia), is essentially unknown.

Sexual reproduction in corals has received increased attention after Connell's review (1973) and the reproductive patterns are sometimes interpreted ecologically (Stimson, 1976, 1978; Rinkevich and Loya, 1979a, b; Kojis and Quinn, 1980, 1981, 1982a, b; SzmantFroelich et al., 1980; Fadlallah, 1981, 1982; Fadlallah and Pearse, 1982a, b; Bothwell, 1982; Tranter et al., 1982). This information has been gathered mainly from Indo-Pacific reefs. Data on sexual reproduction of 
Caribbean corals are much scarcer. During the last decade only Lewis (1974a) published a paper on planulation of Favia fragum (Esper).

The only records on sexual reproduction of the genus Agaricia Lamarck date from early this century (Duerden, 1902; Vaughan, 1910; Mavor, 1915) and are of little ecological importance. This is striking because Agaricia agaricites (Linnaeus) is very abundant as a juvenile in several reef zones, e.g. on Curaçao and Bonaire, Netherlands Antilles (Bak and Engel, 1979), on Jamaica (Rylaarsdam, 1980), and on Barbados (Lewis, 1974b). On Curaçao $58 \%$ of all juvenile scleractinians $(<40 \mathrm{~mm})$ belonged to this species and on Bonaire this percentage was even higher $(79 \%)$. Observations on coral settlement at artificial substrates localized in different reef zones of the Curaçaoan reef confirmed the numerical abundance of Agaricia: Of the hermatypic settlers $69 \%(N=1253)$ belonged to this genus (Van Moorsel, in prep.). Similar results were obtained in Panama (Meyer and Birkeland, 1974). Bak and Engel (1979) concluded that $A$. agaricites maintains itself on the reef by allocating relatively much energy to reproduction.

During my studies on the reproductive effort of Agaricia agaricites an interesting discovery was made: Different growth forms of this species showed significant differences in reproductive characteristics such as colony size at first reproduction, size of planulae and planulation season. This pattern appeared to be parallelled by consistent differences in skeletal morphology. In this paper these data are presented in order to establish $A$. agaricites forma humilis Verrili as a separate species, $A$. humilis, from the other $A$. agaricites forms.

The recognition of such large differences in reproductive strategy allows a better understanding of the potential divergence in life histories of closely related coral species. The differences are explained in relation to the predictability (Grassle, 1973) of their respective reef habitats.

\section{TAXONOMY AND DISTRIBUTION OF AGARICIA ON THE CURAÇAO REEF}

Wells (1973) has condensed the many forms described in Agaricia agaricites to 5. All 5 can be recognized on the reef of Curaçao. On the lower reef slope, 20 to $30 \mathrm{~m}$ depth, unifacial laminae of forma purpurea (Lesueur) can be seen. At shallower depths, colonies form bifacial lobes. In the drop off zone, $10 \mathrm{~m}$ depth, such bifacial lobes dominate strongly and boxlike colonies are formed (forma danai M. E. \& H.). Both forms can grow to a maximum diameter of $60 \mathrm{~cm}$. On the sediment rich reef flat $(<10 \mathrm{~m})$ the colonies grow to only a small size but are still carinate (forma carinata Wells). Submassive colonies of forma agaricites (Linnaeus) can be found in all these zones. Among the 4 of them a gradual shift in shape is observed. Growth form appears to depend strongly on available light, local sedimentation and water turbulence regime. In this paper I shall refer to these 4 forms as A. agaricites. The skeleton displays rather large calices generally, which number about $12 \mathrm{~cm}^{-2}$ (Fig. 1).

In what I call Agaricia agaricites, 2 groups of differently colored colonies could be discemed at the sampling locations. Colonies with orange fluorescent stomodaea were common through the 5 to $35 \mathrm{~m}$ depth range. Brown colonies, which often exhibited a green fluorescence under ultraviolet light, were less common at the same depths, although relatively more abundant at $30 \mathrm{~m}$. Both groups showed an identical change in colony shape with depth.

The fifth form mentioned by Wells, Agaricia agaricites forma humilis Verrill, is found mainly at shallow locations ( $<10 \mathrm{~m}$ depth) although colonies do occur down to $25 \mathrm{~m}$. In contrast to $A$. agaricites, $A$. agaricites forma humilis always has small, densely packed calices ( $\pm 21 \mathrm{~cm}^{-2}$ ), characterized by deep and narrow central pits (Fig. 1). The tuberculous colonies reach a maximum size of $12 \mathrm{~cm}$ only. They are less plate-like, more encrusting and never form bifacial lobes. The skeletal construction is reticulate whereas in A. agaricites longer valleys are often present. In addition there is a difference in septal number (Fig. 1). The mean number of septa of 5 representative calices of forma humilis was $32.2 \pm 2.7(\mathrm{~N}=13$ colonies). In A. agaricites this was $26.7 \pm 2.4(\mathrm{~N}=11$ colonies). This difference is significant ( $p<0.002$, two-tailed Mann Whitney test, Siegel, 1956). Live colonies of A. agaricites forma humilis frequently display white spots lacking zooxanthellae. When subjected to ultraviolet light, the colonies often show green dots, one on each polyp.

The observations are based on Curaçao specimens. Nevertheless it appears that the morphological characteristics and small maximum size of this form are covered rather accurately by the orginal description of Agaricia agaricites humilis (Verrill, 1901). It does not resemble $A$. agaricites var, pusilla Verrill, which is mentioned in combination with $A$. agaricites humilis Verrill by Wells (1973). I studied the syntype specimens of A. agaricites forma humilis (Yale Peabody Museum nr. 4522 and 4538) and decided to choose the latter specimen as the lectotype of the new species A. humilis because of its resemblance with the Curaçao specimens of $A$. humilis, although it has somewhat thicker and less septa (mean 26.5). Specimens of $A$. humilis from Curaçao have been deposited at the Instituut voor Taxonomische Zoölogie, Amster- 

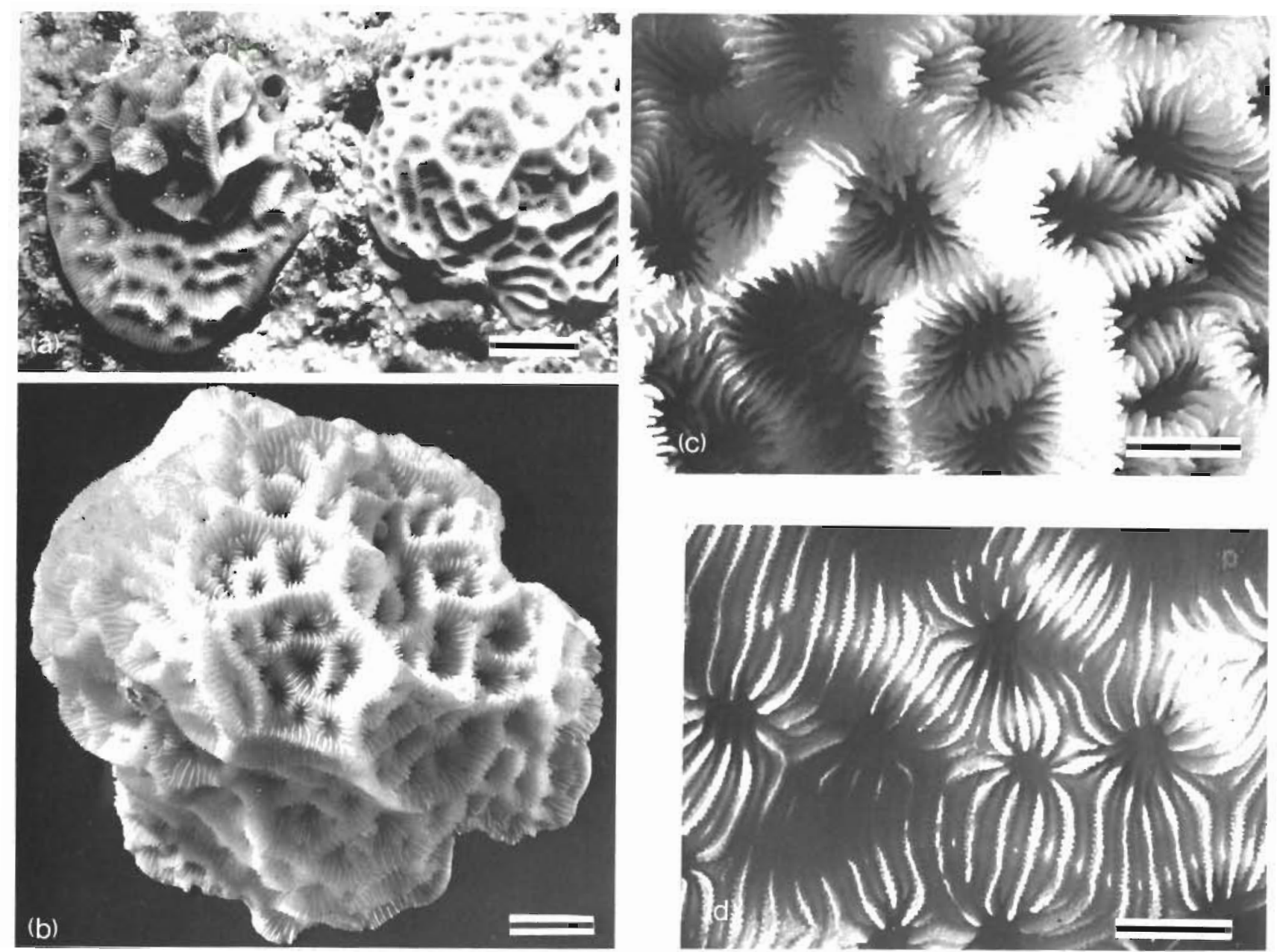

Fig. 1. (a) Live colonies of Agaricia agaricites (left) and A. humilis (right) on the reef near 'Spaanse Water', Curaçao, $10 \mathrm{~m}$ depth. A. agaricites has started to form a bifacial lobe. Light spots are orange fluorescent stomodaea. (b) Skeleton of $A$. humilis colony Collection locality westem asterisk Fig. 2, $9 \mathrm{~m}$ depth. A. humilis is depicted by Roos (1964, Plate XIIb: c) as A. agaricites forma crassa. (c) Detail skeleton of $A$. humilis colony. Collection locality western asterisk Fig. 2, $7.5 \mathrm{~m}$ depth. (d) Detail skeleton of $A$ agaricites colony. Collection locality eastern asterisk Fig. $2,28 \mathrm{~m}$ depth. Scale bars $(\mathrm{a})=10 \mathrm{~mm} ;(\mathrm{b})=5 \mathrm{~mm} ;(\mathrm{c}, \mathrm{d})=2 \mathrm{~mm}$

dam (ZMA Coel. 8323, 8324, 8325, 8326), the Rijksmuseum voor Natuurlijke Historie, Leiden (RMNH Coel. 14845, 14846, 14847), the British Museum (Natural History), London (BMNH 1982.11.24.1, 1982.11.24.2, 1982.11.24.3, 1982.11.24.4), the Yale Peabody Museum, New Haven (YPM 10450, 10451, 10452, 10453) and the Smithsonian Institution, Washington D. C. (USNM 63023, 63024, 63025, 63026).

\section{METHODS}

Between December 1978 and April 1981 samples of Agaricia humilis and $A$. agaricites were collected once or twice a month at 2 localities on the fringing reef along the leeward coast of Curaçao (Netherlands Antilles, Fig. 2). For a description of the reef and the zonation see Bak (1977) and Van den Hoek et al. (1978).

Whole colonies of Agaricia humilis were collected between 5 and $12 \mathrm{~m}$. In $A$. agaricites colony size often

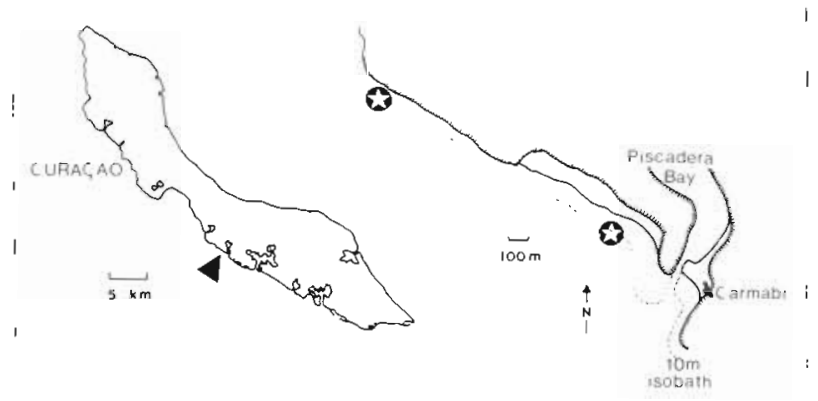

Fig. 2. Sampling sites (asterisks) near Caribbean Marine Biological Institute (Carmabi), Curaçao, Netherlands Antilles 
forced me to take fragments (size at least $60 \times 60 \mathrm{~mm}$, but mostly exceeding $100 \times 100 \mathrm{~mm}$ ) instead of whole colonies. The greatest diameter over the coral surface and, if bifacial lobes were predominant, the greatest height of colonies was measured. A. agaricites was always collected at 10,20 and $30 \mathrm{~m}$ depth. Care was taken to avoid the collection of specimens that were regrowing from partly killed colonies.

The specimens were transported in separate plastic bags to the Caribbean Marine Biological Institute (Carmabi) within $1 \mathrm{~h}$ after sampling. Water in the bags was checked for the occurrence of planulae. The colonies were transferred to 1 to 21 glass aquaria with stagnant unfiltered seawater. This was preferred to an open flow-through system in order to avoid the loss of planulae. Most corals could be kept healthy for weeks if the seawater was replaced every 2 or $3 \mathrm{~d}$. Handling probably stimulated planula release but it is assumed that these planulae would have been shed during the subsequent one week observation period anyway.

The planulae were sufficiently large to be spotted with the naked eye against a black background. During the first week following collection they were counted, pipetted and fixed ( $4 \%$ formaldehyde in sea water) every day or every other day. From each planulating coral 10 planulae, or fewer if not available, were measured using a dissecting microscope along their longitudinal (1) and transverse axis ( $t$ ). Assuming that fixed and therefore often contracted planulae could be described by a spheroid, their volume $V$ was calculated using the equation $\mathrm{V}=\pi / 6 \cdot 1 \mathrm{t}^{2}$.

Finally, the size of the living tissue area was determined: It was covered with aluminum foil which was subsequently weighed.

\section{RESULTS}

\section{Differences in reproductive characteristics of Agaricia humilis and $A$. agaricites}

There was a significant difference in the size at which colonies started producing planulae. The maximum diameter of the smallest planula releasing colonies was $28 \mathrm{~mm}$ in Agaricia humilis, A. agaricites started planulating at $108 \mathrm{~mm}$, a size about 4 times greater (Fig. 3).

In this paper, planulation success is defined as the percentage of colonies/fragments planulating within $1 \mathrm{wk}$ after collection lexcluding the small non planulating colonies) to compare the number of planulating colonies per species.

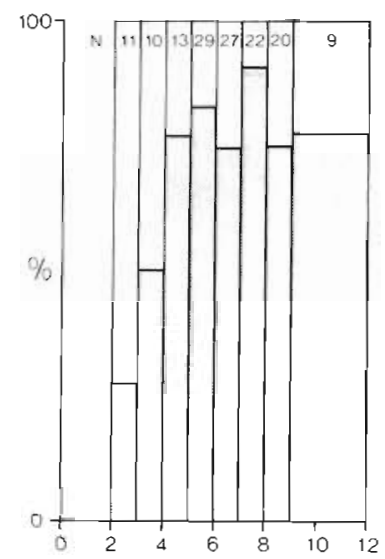

Fig. 3. Planulation success (percentage planulating colonies) in different size classes (maximum colony diameter in $\mathrm{cm}$ ). Top: Agaricia humilis, bottom: A. agaricites. (N: number of colonies or fragments collected in each size class)

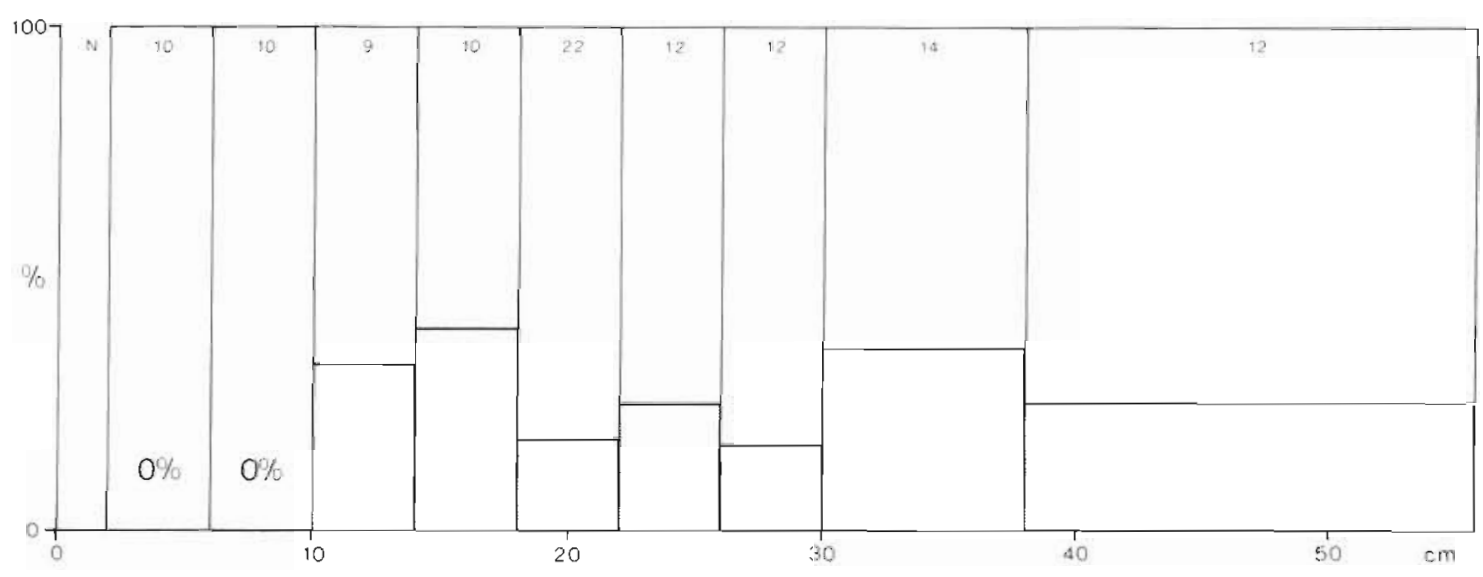



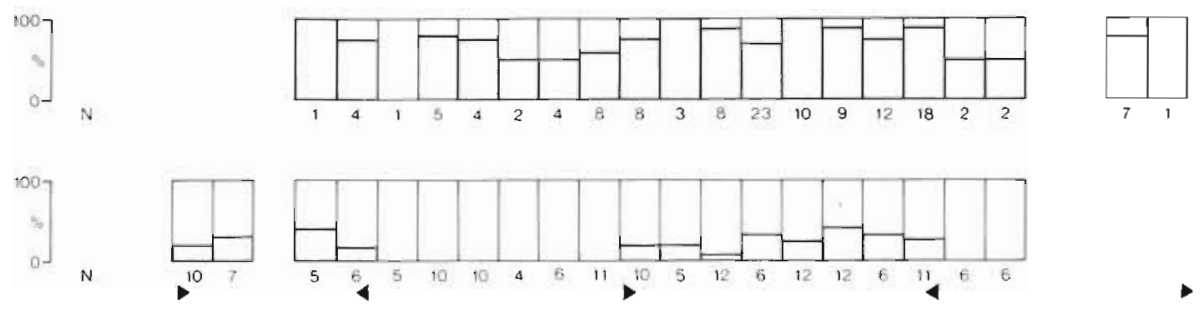

Fig. 4. Planulations success (per-

- centage planulating colonies) and temperature in different months of the year. Top: Agaricia humilis, middle: $A$. agaricites, bottom: temperature $\left({ }^{\circ} \mathrm{C}\right)$. 4 first, respectively last observation of planulating $A$. agaricites each year, 1981 from incidental observations. ( $\mathrm{N}$ : number of colonies or fragments collected each month)

Planulation success through time is shown in Fig. 4. Agaricia humilis planulated throughout the year, while $A$. agaricites released planulae in spring and summer only. I observed the first planulae of $A$. agaricites in 1979 on April 6 and the last on August 20. There are no Curaçao data for June 1979 but at that time I collected planulating colonies of $A$. agaricites at Carrie Bow Cay, Belize. In 1980 the larval release period was from March 4 to October 23. In 1981 the first planulae were detected on April 28. The planulation periods of $A$. agaricites coincided with the annual period of rising sea water temperature (Fig. 4). A. humilis planulated during the whole year, but planulation success was significantly higher during the planulation season of $A$. agaricites ( $82 \%$ ) than in the rest of the year $(64 \%)\left(X^{2}, p<0.05\right)$.

The average planulation success was $78 \%(N=133)$ in Agaricia humilis, 3 times higher than the $26 \%$ $(\mathrm{N}=91)$ of $A$. agaricites. This last figure has been determined by using only specimens sampled during the planulation season. In both species planulation success per size group did not change after the onset of planulation (Fig. 3).

There are several reasons to express reproductive output not per polyp but per colony. If planulae are the result of cross fertilization with subsequent brooding and if all polyps of the same colony originate by division from the same primary polyp, each planula from this colony shares half of its genes with all polyps of this colony. In other words, it is equally related to each of them. Moreover, it is possible that planulae migrate through interpolypal channels: I have observed injection of sea water in polyps of Agaricia agaricites to cause planula release in neighbouring polyps. Planula production cannot be expressed per unit colony weight because difficulties arise when different growth forms are compared. Consequently I use planula production per square unit living tissue area.

The mean planula production in planulating col- onies of Agaricia humilis was 0.86 planulae $\mathrm{cm}^{-2} \mathrm{wk}^{-1}$ $(\mathrm{N}=104)$, with a maximum of $5.2 \mathrm{pl} . \mathrm{cm}^{-2} \mathrm{wk}^{-1}$ (Fig. 5). This is 4 times as much as A. agaricites with planulating colonies producing $0.23 \mathrm{pl} . \mathrm{cm}^{-2} \mathrm{wk}^{-1}$ $(\mathrm{N}=24)$ on average and $2.0 \mathrm{pl} . \mathrm{cm}^{-2} \mathrm{wk}^{-1}$ maximally
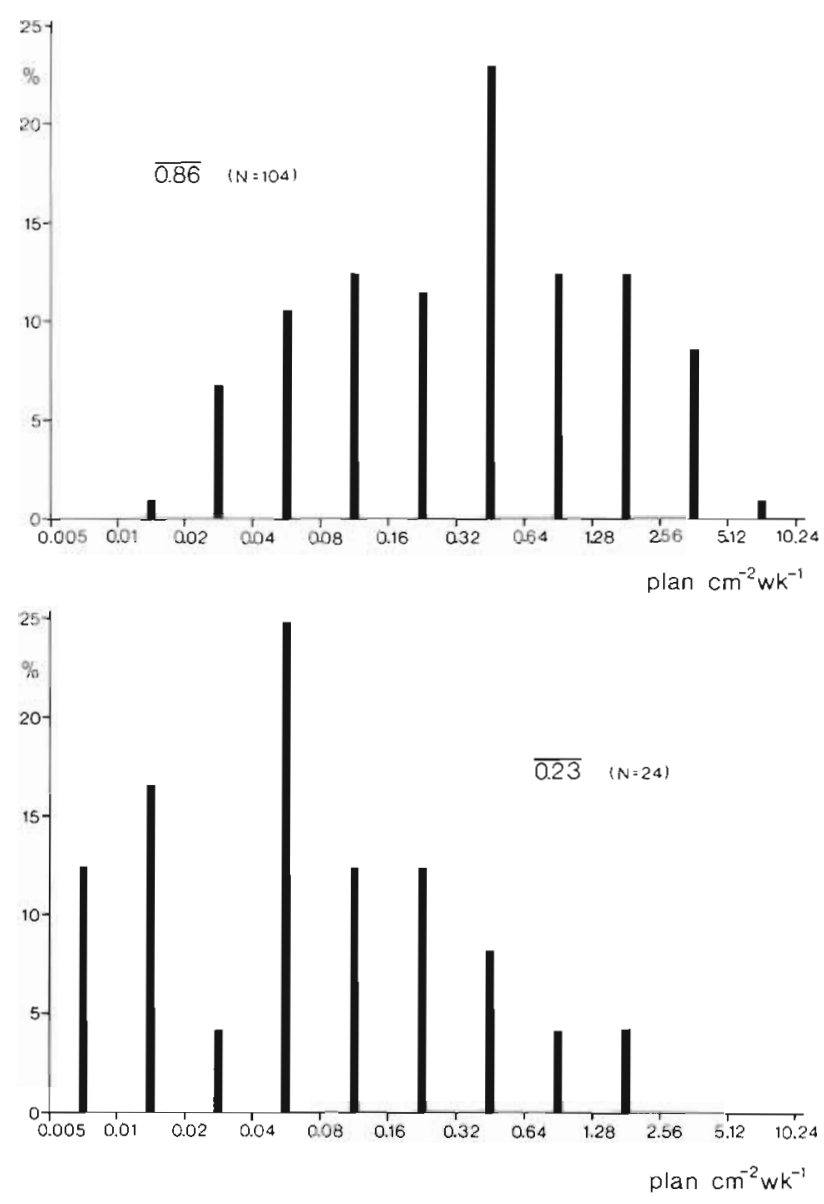

Fig. 5. Production of planulae $\mathrm{cm}^{-2}$ living tissue area $\mathrm{wk}^{-1}$, expressed as frequency of different classes. Top.: Agaricia humilis, bottom: A. agaricites. ( $\mathrm{N}$ : number of colonies or fragments observed planulating) 
(Fig. 5). Planula production per unit tissue area per week was very variable in both species. It could neither be correlated with size groups nor did it show marked trends during the planulation season. No correlation between lunar phase and planula release could be detected.

Planula volume in Agaricia humilis was on the average 5 times smaller than in $A$. agaricites (Fig. 6). Mean volume of $A$. humilis planulae was $0.166 \mathrm{~mm}^{3}$ ( $N=340$, from 46 colonies). Such a volume is represented by a sphaeroid planula with major and minor axes of 0.9 and $0.6 \mathrm{~mm}$, respectively. The largest planula observed had a volume of $0.61 \mathrm{~mm}^{3}$. Planulae of $A$. agaricites had a mean size of $0.860 \mathrm{~mm}^{3}(\mathrm{~N}=141$, from 25 colonies). This corresponds to a planula with axes of 1.6 and $1.0 \mathrm{~mm}$. Maximal planula volume was $2.4 \mathrm{~mm}^{3}$, matching a planula of $3 \mathrm{~mm}$ in length and $1.25 \mathrm{~mm}$ in width. The differences in habit and reproductive characteristics between $A$. humilis and $A$. agaricites are epitomized in Table 1.

The average yearly reproductive effort per unit area is much lower in Agaricia agaricites than in A. humilis. Although the lower planula production per planulating coral of $A$. agaricites is amply compensated by the much bigger planula volume (Figs. 5 and 6 ), a much lower percentage of $A$. agaricites colonies/fragments is found planulating and only during part of the year (Fig. 4).

\section{Differences between two differently colored groups of Agaricia agaricites}

Planulation success in Agaricia agaricites did not change significantly with depth. Only at $30 \mathrm{~m}$ did a significant difference $\left(\mathrm{X}^{2}, \mathrm{p}<0.01\right)$ in planulation success occur between the 2 color groups (see 'Taxonomy and distribution'): $7 \%$ in the colonies with orange fluorescent stomodaea $(\mathrm{N}=14)$ and $64 \%$ in the brown colonies $(\mathrm{N}=11)$. No other differences in life histories and morphology were found.

The differences in reproductive patterns between these color groups are much less pronounced than between Agaricia humilis and A. agaricites. In the comparison of these species the $2 \mathrm{~A}$. agaricites color groups are considered to be conspecific.

\section{Planula release, morphology and behaviour}

Planula release was observed during all times of the day but with a higher frequency in the evening.

Planulae originating from one colony at the same day were rather uniform in volume. An intercolony comparison of planula volumes showed less similarity. For example the volume of 10 planulae from an Agaricia agaricites colony, sampled on August 26 1980 , ranged from 1.1 to $1.4 \mathrm{~mm}^{3}$. The same number of planulae from another colony, sampled on the same day, ranged from 0.22 to $1.08 \mathrm{~mm}^{3}$. There probably is some intracolony synchronization in planula development.

After extrusion most planulae were piriform and displayed free-swimming behaviour for at least a few hours. Swimming was with the aboral pole in front and sometimes accompanied by a nodding or turning movement. Circling also occurred. Creeping, exploring planulae were oblong egg-shaped. After stopping locomotion they could change to an oblate spheroid form and exhibit a spinning movement at one spot. During this phase lipid granulae were sometimes observed to be expelled from the oral pole. Some irregularly shaped planulae were encountered.

If a suitable substrate were present, settlement and metamorphosis could occur within $24 \mathrm{~h}$; however, settling could be postponed for at least $42 \mathrm{~d}$. The diameter of newly settled corals was about $1 \mathrm{~mm}$ in

Table 1. Agaricia humilis and A. agaricites. Habit and reproductive characteristics. Planulation success (percentage planulating colonies) in $A$. agaricites determined by incorporating only specimens sampled during the planulation season. Mean planula production determined by incorporating planulating colonies only

\begin{tabular}{lcc|}
\hline \multicolumn{1}{|c|}{ Parameter } & A. humilis & A. agaricites \\
\hline Maximum colony diameter $(\mathrm{mm})$ & 120 & 600 \\
Polyps $\left(\mathrm{cm}^{-2}\right)$ & 21 & 12 \\
Septa per polyp & 32.3 & 26.7 \\
Maximum diameter of smallest planulating colony $(\mathrm{mm})$ & 28 & 108 \\
Planulation time & whole year & spring/summer \\
Planulation success & $78 \%$ & $26 \%$ \\
Mean number of planulae produced $\left(\mathrm{cm}^{-2} \mathrm{wk}^{-1}\right)$ & 0.86 & 0.23 \\
Maximum number of planulae produced $\left(\mathrm{cm}^{-2} \mathrm{wk}^{-1}\right)$ & 5.3 & 2.0 \\
Mean planula volume $\left(\mathrm{mm}^{3}\right)$ & 0.166 & 0.860 \\
Maximum planula volume $\left(\mathrm{mm}^{3}\right)$ & 0.61 & 2.4 \\
\end{tabular}




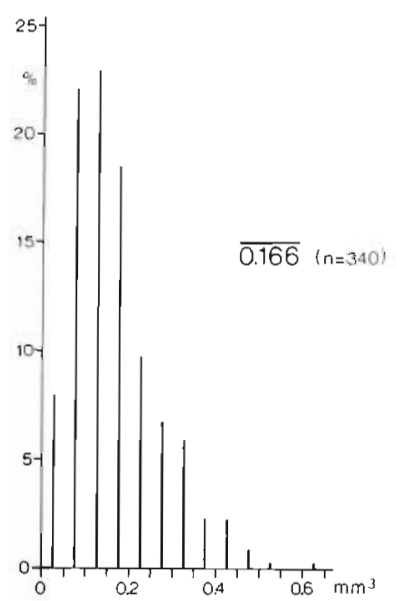

Fig. 6. Volume of planulae of Agaricia humilis (top) and A. agaricites (bottom). Height of bars depicts relative occurrence of size classes. ( $\mathrm{N}$ : number of planulae measured)

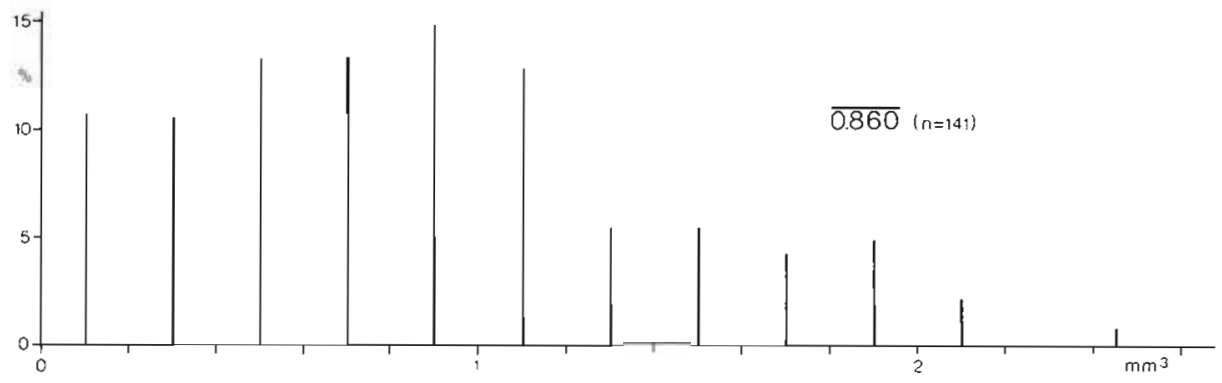

Agaricia humilis and $2 \mathrm{~mm}$ in $A$. agaricites, corresponding to the original planula volume.

Planulae of both species contained green fluorescent particles in areas between the radial fields of zooxanthellae on the oral pole. Newly settled corals could also easily be spotted in ultraviolet light by this striking green fluorescence.

\section{DISCUSSION}

Reproductive strategies of Agaricia humilis and A. agaricites - explanation and comparison with other coral species

It may seem tempting to use the $r-K$ concept in explaining reproductive strategies (review by Stearns, 1976). However, phenomena such as brooding habits in benthic marine invertebrate r-strategists (Menge, 1974; Rinkevich and Loya, 1979b) necessitate the use of additional ecological dimensions to explain the evolution of life histories (Wilbur et al., 1974). Dealing with scleractinia, Rosen (1981) pointed to Grime's $\mathrm{C}-\mathrm{S}-\mathrm{R}$ triangle in which competition, stress tolerance and a ruderal component are mentioned. I prefer to explain the different characteristics of Agaricia humilis and $A$. agaricites separately. The different traits can then be related to the predictability of the habitat of these corals as mostly independent adaptive responses.
Agaricia humilis is numerous on the shallower part of the reef, a habitat where relatively much spatial rearrangement occurs. Bak and Luckhurst (1980) determined the rate of appearance and disappearance of several reef substrates: for 'rock', the most suitable substratum for coral settlement, the relative spatial change gradually decreased from 10 to $40 \mathrm{~m}$ depth indicating the short turnover time of this substratum at the shallow reef. The low predictability of this environment is explained by the frequency of physical and biological disturbances. A. humilis persists under these insecure prospects by allocating much energy to early reproduction. Planulating at a diameter of $28 \mathrm{~mm}$ (compared with $108 \mathrm{~mm}$ in A. agaricites) it seems that the risk of not reproducing, if the onset of reproduction was postponed, cannot be taken.

There is a striking similarity in colony size and age of first reproduction in Agaricia humilis and the coral Stylophora pistillata (Esper) in the Red Sea. Both species start reproducing at a colony diameter of $\pm 30 \mathrm{~mm}$, corresponding to an age of less than $2 \mathrm{yr}$ (Rinkevich and Loya, 1979b; Van Moorsel, in prep.). S. pistillata is larviparous but it has been described as an r-strategist (Loya, 1976). Stimson (1978) supplies more data on size of first reproduction in other corals and reports early sexual maturity especially in corals of shallow water.

Adult colonies of Agaricia agaricites are mainly confined to the more predictable reef zones. Due to the older average successional stage of the communities 
(Connell, 1978), competitive ability will be more important here. In small $A$. agaricites colonies $(<108 \mathrm{~mm})$ all energy is allocated to growth, regeneration and competition. With a diameter growth of $24.5 \mathrm{~mm} \mathrm{yr}^{-1}$ (Bak, 1976) this coral does not planulate until after 4 to 5 yr of unrestricted growth.

Goniastrea australensis (M. E. \& H.), a massive coral, starts reproducing at a small size, but this is probably not reached until 4 to 5 yr (Kojis and Quinn, 1981). This is one of the main reasons why they prefer to call $G$. australensis a K-strategist.

Bak and Engel (1979) did not distinguish Agaricia humilis from $A$. agaricites. They described this species complex as an opportunistic species $A$. agaricites compared to Montastrea annularis Ellis \& Solander. Bak and Engel did not find a higher mortality of their A. agaricites juveniles on the shallow reef in comparison with the deeper reef zones, but they are aware of the fact that this coral settles most abundantly in shallow water where large colonies are scarce and bottom cover is very low. They explain this discrepancy by the slower growth rate of $A$. agaricites in this environment and assume that seasonal or catastrophic mortality occurs and/or that mortality rises with increasing size. Although essentially right this explanation is better understood if one realizes that a large proportion of Bak and Engel's A. agaricites juveniles must have belonged to $A$, humilis, a species with its own life history.

There is strong evidence that sea water temperature fluctuations are of paramount importance in synchronization of reproductive activities in shallow-water temperate species (Giese and Pearse, 1974). My results suggest that such a relationship between sea water temperature and reproduction (Orthon's rule) exists as well on the tropical deep reef of Curaçao with an annual temperature fluctuation of about $4{ }^{\circ} \mathrm{C}$. As to the ultimate cause it is unclear why spring and summer are favorable for planulation of Agaricia agaricites and increased planulation success in $A$. humilis. In A. humilis constraints on colony size and planula production may force this species to planulate through the year. Information on Agaricia species is extremely scarce and species identification confused. All records (Duerden, 1902; Vaughan, 1910; Mavor, 1915) indicate a spring/summer planulation season. Literature data on other Caribbean corals confirm such a season (Lewis, 1974a: Favia fragum) or are indefinite (Duerden, 1902: Manicina areolata (L), F. fragum). So far, $A$. humilis represents the only Caribbean species to substantiate the hypothesis that shallow-water corals planulate year round as opposed to species more characteristic of deeper water being gravid in particular seasons (Stimson, 1978).

My results do not support Stimson's hypothesis that deep-water corals are external fertilizers (Stimson, 1978). Planulating Agaricia agaricites colonies have been collected as deep as $34 \mathrm{~m}$. Alternatively, Kojis and Quinn (1981) found Goniastrea australensis to be externally fertilizing on the reef flat. Nevertheless, Stimson (1978) is probably right in that the frequently disturbed shallow reef results in the selection of species with high reproductive rates. This is certainly the case in $A$. humilis.

The low predictability of the shallow reef also explains the high planulation success and planula production in Agaricia humilis. On the deeper reef $A$. agaricites will be compensated for lower levels of planulation success and planula production by a higher survival rate and longer sequence of reproductive years.

There are no comparative data on planulation success and planula production available. The percentage of reproductive Stylophora pistillata colonies ( $\overline{\mathrm{r}}>40 \mathrm{~mm}$ ) of 82 to $93 \%$ is quite close to values in Agaricia humilis but is derived histologically (Rinkevich and Loya, 1979b).

The large planulae of Agaricia agaricites probably have more yolk and are therefore better suited to find and to defend their place of settlement. This is of crucial importance in a competitive environment. For A. humilis planulae ample substrata will be available in the shallow reef environment. $A$. humilis employs these substrata through the production of many small larvae instead of a few big ones. This ensures the survival of at least some offspring under the unpredictable regime of the shallow reef environment.

A greater number of planulae of an Agaricia humilis population will possibly contribute to dispersal. Reduced dispersal promotes processes like genetic drift and may explain why $A$. agaricites seems to consist of several differently colored forms. A humilis appears to be more uniform throughout its distribution on the Netherlands Antilles (own obs.)

In addition to reproductive patterns skeletal morphology displays adaptations to the environment. Small colony size and lack of bifacial lobes make Agaricia humilis colonies less vulnerable to strong water movement in the shallow reef environment, than A. agaricites colonies. The encrusting colony base moreover promotes firm attachment to the substratum. On the more constant deep reef $A$. agaricites can grow to a large size. The plate-like growth form enables A. agaricites to overtop other organisms, a characteristic which facilitates spatial competition.

Differences in septal number and polyp density may be explained by different reproductive requirements. The larger polyp density and higher number of septa per polyp in Agaricia humilis indicate a possible increase in the number of gonads. Rinkevich and Loya 
(1979a), Fadlallah (1981) and Fadlallah and Pearse (1982a) hypothesize that a reproductive pattern could be a response to the design of the polyp and skeleton. I suggest that skeletal characteristics can be a response to reproductive requirements. There will be a strong selection in favor of characteristics which directly contribute to an optimal number of reproductive offspring.

Alternative interpretations of the observed differences between Agaricia agaricites and $A$. humilis are possible. However, the coherence of the characteristics in view of the suggested relation with the predictability of the habitat strongly favors this explanation.

Planula behaviour after release was similar to other coral species (Harrigan, 1972; Lewis, 1974a; Rinkewich and Loya, 1979a). No filaments and nodules have been observed as in Stylophora pistillata (Rinkevich and Loya, 1979a). But Agaricia larvae have other features in common with $S$. pistillata, such as the ejection of fat-like granulae from the oral pole and the presence of green fluorescent particles around the oral pole. I suggest that the release of lipids is a mechanism to decrease the buoyancy of a planula in order to reach the substratum. In Agaricia planulae the arrangement of the fluorescent particles between rows of zooxanthellae prevents them from screening direct photosynthetic active radiance (PAR) without the loss of their possible role of channeling UV light into photosynthetic pathways (Kawaguti, 1969). However, both suggestions need to be tested.

\section{Related perspectives in other benthic invertebrates}

The reproductive characteristics of these Agaricia species and their relation to the environment are not unique. Similar features are recently found in other related benthic invertebrate species or populations living in habitats of different predictability.

In 3 species of Zoanthus the smallest, from the most variable environment, showed the highest fertility and the longest reproductive period (Karlson, 1982).

In shallow-water $(<20 \mathrm{~m})$ cumacean species the number of eggs per brood tended to be greater than in deeper water species. This was probably related to relatively unstable temperatures and salinities and higher predation in shallow water (Corey, 1981).

Hines (1979) compared 3 species of intertidal barnacles. The species living at the highest level had a small body size, an early age of first reproduction and produced the smallest eggs, but its reproductive season lasted longest and the reproductive effort (per year) was greatest. The species from the lowest level had opposite habits and the species sandwiched between them showed an intermediate pattern.

Spight (1979) compared 2 marine snails, Thais emer- ginata (Gmelin) and T. lamellosa (Deshayes). The former occurs higher in the intertidal than the latter, resulting in a higher mortality. The harsher environment precludes a long juvenile period, large body size, large clutch size and short reproductive period in T. emerginata.

Littorina rudis Heller populations from exposed bedrock had a high embryo production but the smallest embryos (Faller-Fritsch, 1977). The lack of large individuals necessitates an increase in the reproductive role of the small individuals and selection has favored maturity at a small size. In sheltered populations there are advantages in quickly attaining a refuge in size before the commencement of reproduction.

Depth and exposure were important parameters in all these studies, but other habitat constituents can also determine predictability. Switzer-Dunlap and Hadfield (1979) described 4 aplysiid gastropods, the most opportunistic species living on an unstable supply of its main food. It has a short life span and a small maximum size, reproduces at an early age and spawns small egg masses very frequently. Another species presumably has a year round food supply and its reproductive characteristics are the opposite. The remaining 2 show intermediate values which can also be related to the degree of predictability of their algal food supply.

Reproductive patterns in such species resemble those of Agaricia humilis and $A$. agaricites. The species or population from the most unpredictable habitats (shallow, high in the intertidal, exposed, with unstable food supply) is comparatively small and/or short lived, reaches maturity early and/or at a small size, has a long reproductive period and many small offspring which constitute a relatively high yearly reproductive output. Related species from more stable environments show the reverse characteristics.

In comparing reproductive patterns of different species there is always the risk of dealing with 'accidents of ancestry' which place limits on adaptive variation (Strathman, 1977). In my results and some of the cited studies this phylogenetic effect is considered to be minimal because the influence of habitat differences was studied within the same genus.

Physical and biological parameters have often been related to the distribution of coral species directly. However they also create an environmental predictability which affects the reproductive patterns by natural selection. This again influences the abundance and size distribution of a population which is therefore molded by the above mentioned parameters directly as well as indirectly.

Acknowledgements. The Caribbean Marine Biological Institute (Carmabi), Curaçao provided research facilities. The 
help of staff, diving buddies, other personnel and students during my stay at the Carmabi is greatly acknowledged. I would like to thank Dr. R. P. M. Bak for introducing me to the field of coral reef ecology and his supervision during all phases of the investigation. Professor Dr. G. P. Baerends and Dr. R. W. M. Van Soest also gave stimulating critique on earlier versions of the manuscript. L. Delvoye kindly provided some of his results which were included in the Agaricia humilis planulation data

This investigation was supported by a grant from the Netherlands Foundation for the Advancement of Tropical Research (WOTRO) W84 - 167.

\section{LITERATURE CITED}

Bak, R. P. M. (1976). The growth of coral colonies and the importance of crustose coralline algae and burrowing sponges in relation with carbonate accumulation. Neth. J. Sea Res. 10: 285-337

Bak, R. P. M. (1977). Coral reefs and their zonation in the Netherlands Antilles. Am. Ass. Pet. Geol. Stud. Geol. 4 $3-16$

Bak, R. P. M., Engel, M. S. (1979). Distribution, abundance and survival of juvenile hermatypic corals (Scleractinia) and the importance of life history strategies in the parent coral community. Mar. Biol 54: 341-352

Bak, R. P. M., Luckhurst, B. E. (1980). Constancy and change in coral reef habitats along depth gradients at Curaçao. Oecologia 47: 145-155

Bothwell, A. M. (1982). Fragmentation, a means of asexual reproduction and dispersal in the coral genus Acropora (Scleractinia: Astrocoeniida: Acroporidae) - a preliminary report. In: Gomez, E. D., Birkeland, C. E., Buddemeier, R. W., Johannes, R. E., Marsh, J. A., Jr., Tsuda, R. T. (eds.) Proceedings of the fourth international coral reef symposium, Vol. 2. Marine Sciences Center, University of the Philippines, Manila, p. 137-144

Clarke, A. (1979). On living in cold water: K-strategies in Antarctic benthos. Mar. Biol. 55: 111-119

Connell, J. H. (1973\}. Population ecology of reef building corals. In: Jones, O. A., Endean, R. (eds.) Biology and geology of coral reefs, Vol. 2. Academic Press, New York, p. $205-245$

Connell, J. H. (1978). Diversity in tropical rain forests and coral reefs. Science, N. Y. 199: 1302-1310

Corey, S. (1981). Comparative fecundity and reproductive strategies in 17 species of the Cumacea (Crustacea: Peracarida). Mar. Biol. 62: 65-72

Dana, T. F. (1976). Reef-coral dispersion patterns and environmental variables on a Caribbean coral reef. Bull. mar. Sci. 26: 1-13

Duerden, J. E. (1902). West Indian madreporian polyps. Mem. natn. Acad. Sci. 8 (7th Memoir) : 399-649

Fadlallah, Y. H. (1981). The reproductive biology of three species of corals from central California. PH. D. thesis, University of California, Santa Cruz

Fadlallah, Y. H. (1982). Reproductive ecology of the coral Astrangia lajollaensis: sexual and asexual patterns in a kelp forest habitat. Oecologia 55: 379-388

Fadlallah, Y. H., Pearse, J. S. (1982a). Sexual reproduction in solitary corals: overlapping oogenic and brooding cycles and benthic planulas in Balanophyllia elegans. Mar. Biol. 71: $223-231$

Fadlallah, Y. H., Pearse, J. S. (1982b). Sexual reproduction in solitary corals: synchronous gametogenesis and broadcast spawning in Paracyathus stearnsii. Mar. Biol. 71: 233-239
Faller-Fritsch, R. J. (1977). Reproductive strategies of the winkle Littorina rudis in relation to population dynamics and size structure. In: Keegan, B. F., Ceidigh, P. O., Boaden, P. J. S. (eds.) Biology of benthic organisms. Pergamon Press, Oxford, New York, p. 225-231

Grassle, J. F. (1973). Variety in coral reef communities. In: Jones, O. A., Endean, R. (eds.) Biology and geology of coral reefs, Vol. 2. Academic Press, New York, p. 247-270

Giese, A. C., Pearse, J. S. (1974). Introduction, general principles. In: Giese, A. C., Pearse, J. S. (eds.) Reproduction of marine invertebrates, I, Acoelomate and pseudocoelomate metazoans. Academic Press, New York and London, p. $1-49$

Harrigan, J. F. (1972). The planula larva of Pocillopora damicornis: lunar periodicity of swarming and substratum selection behaviour. $\mathrm{Ph}$. D thesis, University of Hawaii

Hines, A. H. (1979). The comparative reproduction ecology of three species of intertidal barnacles. In: Stancyk, S. E. (ed.) Reproductive ecology of marine invertebrates. University of South Carolina Press, Columbia, p. 213-233

Karlson, R. H. (1982). Reproductive patterns in Zoanthus spp. from Discovery Bay, Jamaica. In: Gomez, E. D., Birkeland, C. E., Buddemeier, R. W., Johannes, R. E., Marsh, J. A., Jr., Tsuda, R. T. (eds.) Proceedings of the fourth international coral reef symposium, Vol. 2. Marine Sciences Center, University of the Philippines, Manila, p. 700-704

Kawaguti, S. (1969). Effect of the green fluorescent pigment on the productivity of the reef corals. Micronesia 5: 313

Kojis, B. L., Quinn, N. J. (1980). Mode and timing of sexual reproduction in some members of the hermatypic coral family Faviidae. Am. Zool. 20: 819

Kojis, B. L., Quinn, N. J. (1981). Aspects of sexual reproduction and larval development in the shallow water hermatypic coral Goniastrea australensis (Edwards and Haime, 1857). Bull. mar. Sci. 31: 558-573

Kojis, B. L., Quinn, N. J. (1982a). Reproductive strategies of four species of Porites (Scleractinia). In: Gomez, E. D., Birkeland, C. E., Buddemeier, R. W., Johannes, R. E., Marsh, J. A., Jr., Tsuda, R. T. (eds.) Proceedings of the fourth international coral reef symposium, Vol. 2. Marine Sciences Center, University of the Philippines, Manila, p. 145-151

Kojis, B. L., Quinn, N. J. (1982b). Reproductive ecology of two Faviid corals (Coelenterata: Scleractinia). Mar. Ecol. Prog. Ser. 8: 251-255

Lewis, J. B. (1974a). The settlement behaviour of planulae larvae of the hermatypic coral Favia fragum (Esper). J. exp. mar. Biol. Ecol. 15: 165-172

Lewis, J. B. (1974b). Settlement and growth factors influencing the contagious distribution of some Atlantic reef corals. In: Cameron, A. M., Campbell, B. M., Cribb, A. B., Endean, R., Jell, J. S., Jones, O. A., Mather, P., Talbot, F. $H$. (eds.). Proceedings of the second international symposium on coral reefs. The Great Barrier Reef committee, Brisbane, p. 201-206

Loya, Y. (1976). The Red Sea coral Stylophora pistillata is an r-strategist. Nature, Lond. 259: 478-480

Mavor, J. W. (1915). On the development of the coral Agaricia fragilis Dana. Proc. Am. Acad. Arts Sci. 51: 483-511

Menge, B. A. (1974). Effect of wave action and competition on brooding and reproductive effort in the sea star Leptasterias hexactis. Ecology 55: 84-93

Meyer, C. L., Birkeland, C. E. (1974). Marine studies. In: Rubinoff, R. W. (ed.) Environmental monitoring and baseline data compiled under the Smithsonian Institution Environmental Sciences program. Smithsonian Tropical 
Research Institution, Canal Zone, Balboa, p. 134-137, 242, 250

Ohlhorst, S. L. (1980). Jamaican coral reefs: important biological and physical parameters. Ph. D. thesis, Yale University

Ott, B. (1975). Community patterns on a submerged barrier reef at Barbados West Indies. Int. Revue ges. Hydrobiol. 60: 719-736

Perron, F. E. (1981). Larval biology of six species of the genus Conus (Gastropoda: Toxoglossa) in Hawaii, U.S.A. Mar. Biol. 61: 215-220

Rinkevich, B., Loya, Y. (1979a). The reproduction of the Red Sea coral Stylophora pistillata, I. Gonads and planulae. Mar. Ecol. Prog. Ser. 1: 133-144

Rinkevich, B., Loya, Y. (1979b). The reproduction of the Red Sea coral Stylophora pistillata, II. Synchronization in breeding and seasonality of planulae shedding. Mar. Ecol. Prog. Ser. 1: 145-152

Roberts, H. H., Murray, S. P., Suhayda, J. N. (1977). Physical processes in a fore-reef shelf environment. In: Taylor, D. L. (ed.) Proceedings of the third international symposium on coral reefs. School of Marine and Atmospheric Sciences, University of Miami, Miami, p. 507-515

Roos, P. J. (1964). The distribution of reef corals in Curaçao. Stud. Fauna Curaçao 20: 1-51

Rosen, B. R. (1981). The tropical high diversity enigma - the coral's eyes view. In: Forey, P. L. (ed.) The evolving biosphere (Chance, change and challenge). British Museum (Natural History), London and Cambridge University Press, Cambridge, p. 103-129

Rylaarsdam, K. (1980). Life histories and abundance patterns of some common Caribbean reef corals. Ph. D. thesis, The Johns Hopkins University, Baltimore

Siegel, S. (1956). Nonparametric statistics for the behavioural sciences. McGraw-Hill Kogakusha, Ltd., Tokyo

Spight, T. M. (1979). Environment and life history: the case of two marine snails. In: Stancyk, S. E. (ed.) Reproductive ecology of marine invertebrates. University of South Caroline Press, Columbia, p. 135-143

Spight, T. M. (1981). Latitude and prosobranch larvae: whose veligers are found in tropical waters? Ecosynthesis 1: $29-52$

Stearns, S. C. (1976). Life history tactics: a review of the ideas. Q. Rev. Biol. 51: 3-47
Steele, D. H. (1977), Correlation between egg size and developmental period. Am. Nat. 111: 371-372

Stimson, J. S. (1976). Reproduction of some common Hawaiian reef corals. In: Mackie, G. O. (ed.) Coelenterate ecology and behaviour. Plenum Press, London and New York, p. 271-279

Stimson, J. S. (1978). Mode and timing of reproduction in some common hermatypic corals of Hawail and Enewetak. Mar. Biol. 48: 173-184

Strahtmann, R. R. (1977). Egg size, larval development and juvenile size in benthic marine invertebrates. Am. Nat. 111: 373-376

Switzer-Dunlap, M., Hadfield, M. G. (1979). Reproductive patterns of Hawaiian aplysiid gastropods. In: Stancyk, S. E. (ed.) Reproductive ecology of marine invertebrates. University of South Carolina Press, Columbia, p. 199-210

Szmant Froelich, A., Yevich, P., Pilson, M. E. Q. (1980). Gametogenesis and early development of the temperate coral Astrangia danae (Anthozoa: Scleractinia). Biol. Bull. mar. biol. Lab., Woods Hole 158: 257-269

Todd, C. D., Doyle, R. W. (1981). Reproductive strategies of marine invertebrates. A settlement-timing hypothesis. Mar. Ecol. Prog. Ser. 4: 75-83

Tranter, P. R. G., Nicholson, D. N., Kinchington, D. (1982). A description of spawning and post-gastrula development of the cool temperate coral Caryophyllia smithi. J. mar. biol. Ass. U. K. 62: 845-854

Van den Hoek, C., Breeman, A. M. Bak, R. P. M., Van Buurt, G. (1978). The distribution of algae, corals and gorgonians in relation to depth, light attenuation, water movement and grazing pressure in the fringing reef of Curaçao, Netherlands Antilles. Aquat. Bot. 5: 1-46

Vaughan, T. W. (1910). The recent Madreporia of Southern Florida. Carnegie Instn Wash. Yearbook 9: 135-144

Verrill, A. E. (1901). Comparisons of the Bermudian, West Indian and Brazilian coral faunae. Trans. Conn. Acad. Arts Sci. 11: 169-206

Wells, J. W. (1973). Coral reef project - papers in memory of Dr. Thomas F. Goreau. 2. New and old scleractinian corals from Jamaica. Bull. mar. Sci 23: 16-58

Wilbur, H. M., Tinkle, D. W., Collins, J. P. (1974). Environmental certainty, trophic level and resource availability in life history evolution. Am. Nat. 108: 805-817 